Teologia i Moralność, Volumen 13(2018), numer 1(23)

doi: 10.14746/tim.2018.23.1.7

\author{
MACIEJ OLCZYK \\ Uniwersytet im. Adama Mickiewicza w Poznaniu \\ Wydział Teologiczny
}

\title{
Edukacja seksualna jako wychowanie do miłości. Niezmienne pryncypia i nowe wyzwania w świetle Amoris laetitia 259-290
}

Zagadnienie edukacji seksualnej wzbudza w przestrzeni publicznej żywe dyskusje i polemiki. Dotyczą one zasadniczo treści programowych oraz wizji antropologicznej, w kontekście której dokonywać ma się wychowanie dzieci i młodzieży w tak wieloaspektowej sferze, jaką jest seksualność człowieka. W adhortacji Amoris laetitia papież Franciszek wychodzi naprzeciw toczącym się sporom i zachęca do pogłębionej refleksji nad tym zagadnieniem w świetle pryncypiów wychowawczych pedagogiki personalistycznej inspirowanej mądrością Ewangelii. Franciszek wypowiada zdecydowane „Tak” dla edukacji seksualnej ${ }^{1}$, stwierdzając jednoznacznie, że edukacja ta ma sens tylko wtedy, gdy jest wychowaniem do miłości rozumianej jako wzajemny dar z siebie (por. AL, nr 280). Papież przypomina niezmienne pryncypia, a zarazem kieruje wzrok ku nowym wyzwaniom, chociażby ku tym, jakie niesie ze sobą problematyka kulturowych uwarunkowań rozumienia ludzkiej płciowości (por. AL, nr 285-286).

\section{Doniosłość wychowania etycznego i jego instrumentarium}

Świadomy przemian cywilizacyjnych oraz wyzwań pedagogicznych pojawiających się we współczesnym świecie, Franciszek, podejmując kwestie wychowania dzieci i młodzieży, zwraca się najpierw do rodziców. Rodzina jest pierwszą i niezastąpioną wspólnotą wychowawczą, a rodzice mają niekwe-

\footnotetext{
${ }^{1}$ Dokładnie tak brzmi jeden z podtytułów rozdziału VII adhortacji poświęcony wychowaniu.
} 
stionowany wpływ na rozwój moralny swoich dzieci. Trzeba, aby zaakceptowali ten fakt i podjęli tę odpowiedzialność świadomie, z entuzjazmem oraz rozsądnie i we właściwy sposób (por. AL, nr 259). Kreśląc przed rodzicami to zadanie, papież podaje kilka podpowiedzi, na co należałoby zwrócić uwagę w wychowaniu etycznym, którego częścią jest właściwie rozumiana edukacja seksualna. Wskazówki te uwzględnić powinni również i ci, którzy w instytucjonalny sposób wspomagają rodziców w wychowaniu ich dzieci.

\section{a) Gdzie są dzieci? Czas ważniejszy niż przestrzeń}

Fundamentalna misja rodziny jako środowiska wychowawczego wyraża się przez wsparcie, towarzyszenie oraz prowadzenie dzieci i młodzieży ku dorosłości, nieustanne szukanie nowych metod i środków, aby odpowiadać na pojawiające się w tym względzie trudności i wyzwania. Rodzice mają aktualnie - bardziej niż kiedykolwiek wcześniej - obowiązek bacznej obserwacji tego, na co mogą być narażone ich dzieci.

W tym celu [rodzic] nie może unikać pytań o to, kim są ci, którzy zajmują się zapewnianiem im zabawy i rozrywki, którzy wchodzą do ich domów przez ekrany, kim są ci, którym je powierza, aby je prowadzili w wolnym czasie. Tylko chwile, jakie z nimi spędzamy, rozmawiając z prostotą i miłością o rzeczach ważnych i stwarzanie przez nas godnych możliwości, które mogłyby wypełnić ich czas wolny, pozwalają na uniknięcie szkodliwej inwazji. Czuwanie jest zawsze konieczne. Pozostawienie ich samym sobie nigdy nie prowadzi do niczego dobrego. Rodzice powinni ukierunkowywać i przestrzegać dzieci i młodzież, aby umiały sobie poradzić z sytuacjami, w jakich mogą się znaleźć, jak na przykład zagrożenia agresją, wykorzystaniem lub narkomanią (AL, nr 260).

Tak rozumiana prewencja nie może być jednak uznana za jedyny skuteczny środek wychowawczy. Zapobieganie złu, przestrzeganie przed nim, jakkolwiek ważne i pożyteczne, nie może stać się celem nadrzędnym wychowania, gdyż „obsesja nie wychowuje i nie można mieć kontroli nad wszystkimi sytuacjami” (AL, nr 261). Już w tym miejscu warto zauważyć, że powyższe spostrzeżenie o charakterze bardzo ogólnym, iż „obsesja nie wychowuje”, może być odniesione również do wychowania seksualnego. Etyka negatywistyczna, polegająca jedynie na straszeniu konsekwencjami pewnych zachowań, nie zdała i nie zdaje egzaminu. Potrzeba przede wszystkim działań mających na względzie pozytywny przekaz i kształtowanie postaw afirmacyjnych w stosunku do osoby i jej płciowości.

W tym kontekście pojawia się papieskie wyrażenie, że „czas jest ważniejszy niż przestrzeń” (AL, nr 261), mające uwrażliwić rodziców na fakt, że 
ważniejsze od kontrolowania środowisk, w których przebywa dziecko, jest towarzyszenie mu w wypracowaniu właściwych sposobów reagowania i przeżywania kontaktu ze światem, aby wykształcić w nim umiejętność dojrzałego korzystania z wolności. Zdaniem papieża, o wiele ważniejsze od kontrolowania tego, gdzie dziecko jest w danej chwili i z kim się spotyka, będzie pytanie o to, ,gdzie jest w sensie egzystencjalnym, gdzie się mieści z punktu widzenia swoich przekonań, swoich celów, swoich pragnień, swoich planów życiowych" (AL, nr 261). Ta cenna obserwacja Ojca Świętego powinna być jednak uzupełniona pedagogicznym spostrzeżeniem, że wspomniane powyżej egzystencjalne ,gdzie” dzieci i młodzieży rodzi się w realnym kontekście świata rówieśników, wpływów mediów oraz innych oddziaływań (anty)wychowawczych. Dlatego roztropni rodzice nie mogą rezygnować z czuwania nad tym codziennie doświadczanym, środowiskowym „gdzie”, w którym rozgrywa się wymiana myśli, przekaz poglądów i kształtowanie postaw.

Papież zwraca uwagę, że wychowanie moralne nie może być nigdy przez rodziców scedowane na jakąkolwiek instytucję. Oni są pierwszymi i najbardziej uprawnionymi wychowawcami, gdyż kształtowanie postaw moralnych opiera się przede wszystkim na zaufaniu, jakim dziecko od pierwszych chwil życia darzy swoich rodziców. Przyjmuje i naśladuje określone zachowania, gdyż widzi je u rodziców uważanych za godnych zaufania, uznanych za autorytety. Dziecko, wyczuwając, że jest kochane i cenione przez swoich rodziców, odwdzięcza się im w ten sposób, że przyjmuje proponowany przez nich styl życia. Natomiast ewentualna nieobecność rodziców przy dziecku, emocjonalne zaniedbania, powodują jego cierpienie, a nawet niesione przez całe życie zranienia, co odbija się często w moralnym zachowaniu dzieci wnoszonym dalej w dorosłość (por. AL, nr 263).

\section{b) Krzewienie odpowiedzialnej wolności: rola sumienia i cnót}

Wychowanie, a zwłaszcza wychowanie w tak delikatnej sferze, jaką jest ludzka płciowość, jest przede wszystkim pomaganiem w osiąganiu odpowiedzialnej wolności, zdolnej do podejmowania rozsądnych wyborów i decyzji (por. AL, nr 263). Oznacza to dla rodziców zaangażowanie się w wychowanie woli swoich dzieci, aby nauczyły się chcieć tego, co jest rzeczywistym dobrem dla nich samych oraz dla ich bliźnich. Papież sugeruje, że

kształtowanie moralne powinno dokonywać się zawsze za pomocą metod aktywnych i dialogu edukacyjnego, angażujących wrażliwość i język właściwy dzieciom. Ponadto, kształtowanie to powinno się dokonywać w sposób indukcyjny, aby dziecko mogło samo dojść do odkrycia znaczenia pewnych wartości, zasad i norm, a nie poprzez narzucanie ich jako niepodważalnych prawd (AL, nr 264). 
Dzieci i młodzież powinny być stopniowo i proporcjonalnie do ich wieku wprowadzane w świat wartości, norm i ocen moralnych, poprzez uświadamianie im, że wartości są realizowane przez ludzi w sposób bardziej lub mniej doskonały (AL, nr 272). Zdaniem papieża, ,skuteczna formacja etyczna oznacza ukazanie osobie, jak bardzo dobre działanie jest także korzystne dla niej samej” (AL, nr 265). Chodzi o to, aby w procesie wychowawczym dzieci i młodzież uczyły się nie tylko właściwie oceniać czy wiedzieć, co należy czynić, ale przede wszystkim, aby zdobyły niezachwiane przekonanie o tym, co ma znaczenie priorytetowe. W świetle tego, co poznają za najważniejsze w ich życiu, będą mogły ukierunkować swoją wolność. W procesie tym niezastąpioną rolę odgrywa ludzkie sumienie. To ono pozwala odkryć to, co priorytetowe: prowadzi do spotkania we wnętrzu człowieka z głosem samego Boga, który objawia osobie jej powołanie oraz drogę jego realizacji. Pomocą na tej drodze jest prawo moralne rozbrzmiewające w sumieniu i objawiające się poprzez konkretne sądy powinnościowe: czyń to, tamtego unikaj. Nie zawsze jednak człowiek, zwłaszcza człowiek młody, łatwo podąża za głosem sumienia. Franciszek zauważa, że choć

sumienie dyktuje nam określony osąd moralny, czasami większą władzę mają inne rzeczy, które nas pociągają, jeśli nie udało nam się dojść do tego, aby dobro zrozumiane przez umysł zakorzeniło się w nas jako głęboka skłonność emocjonalna, jako zamiłowanie do dobra, które ma większe znaczenie niż inne atrakcje i pozwala nam dostrzec, że to, co pojęliśmy jako dobro, jest także dobrem „dla nas” tu i teraz (AL, nr 265).

Zarysowana powyżej trudność, polegająca na uleganiu bodźcom silniejszym od mocy sądu sumienia, zaznacza się bardzo wyraźnie w sferze ludzkiej seksualności powiązanej ze światem doznań zmysłowych i przeżyć emocjonalnych. Nie ma łatwego porozumienia pomiędzy ludzkim „wiem” a ludzkim „czuję", wręcz przeciwnie można tu mówić o pewnym duchowym rozdarciu, które teologia katolicka interpretuje jako skutek grzechu pierworodnego (por. Görres 1997, s. 20). Sfera bodźcowo-pożądliwa z trudem daje się ukierunkować przez rozumne poznanie dobra i dlatego konieczny jest tu stały wysiłek edukacyjny. Chodzi w nim nie tylko o to, aby przekazać teoretycznie wiedzę o dobru moralnym (wartości, zasady, normy), lecz sprawić, aby w wychowanku zrodziło się zamiłowanie do dobra, by nie tylko dobro poznał, ale i je pokochał, by stało się ono dla niego drogie, cenne, poruszające świat jego emocji. Tylko takie doświadczenie i przeżycie dobra, które angażuje osobę na płaszczyźnie intelektualnej i emocjonalnej, może utrwalić w niej skłonności zdolne przeciwstawieniu się zmysłowym impulsom i emocjonalnym bodźcom.

W ten sposób dochodzimy do drugiego ważnego ogniwa formacji etycznej, jakim jest rozwijanie sprawności umacniających wolę, aby w sposób ła- 
twy i chętny wybierała moralne dobro. Sprawności te etyka nazywa cnotami. Papież Franciszek definiuje cnotę jako

przekonanie, które przekształciło się w wewnętrzną i stabilną zasadę działania. Życie cnotami buduje zatem wolność, umacnia ją i wychowuje, chroniąc osobę przed staniem się niewolnikiem dehumanizujących i aspołecznych skłonności kompulsywnych. Bowiem sama godność człowieka wymaga, aby każdy „działał według świadomego i wolnego wyboru, to znaczy osobiście, poruszony i kierowany od wewnątrz (GS 17)" (AL, nr 267).

Rozwijanie sprawności moralnych dokonuje się poprzez powtarzanie aktów danej cnoty w sposób świadomy, dobrowolny i konsekwentny. Zadaniem wychowawcy i systemu wychowawczego jest zagwarantowanie dogodnych warunków, aby dzieci i młodzież mogły kształtować w sobie sprawności ukierunkowujące je na autentyczne dobro moralne. Czy dzieje się tak podczas zajęć edukacji seksualnej? Warto w tym kontekście zapytać: Czy przypadkiem niektóre modele tzw. wychowania seksualnego, skupiające np. większą uwagę na promowaniu antykoncepcji niż na rozwijaniu zdolności panowania nad sobą, tym samym nie przybierają charakteru wybitnie antywychowawczego? Edukacja moralna, której część stanowi odpowiedzialnie prowadzona edukacja seksualna, nie jest tłumieniem wolności, lecz jej kultywowaniem. Chodzi tu o kultywowanie wolności na miarę osoby ludzkiej, zdolnej do ukierunkowania swoich spontanicznych odruchów i naturalnych popędów w taki sposób, aby stawały się one wyrazem międzyosobowej miłości, prowadzącej do płodnej komunii.

\section{c) Wartość sankcji i postawa powściągliwości}

W wychowaniu etycznym jest, zdaniem Franciszka, również miejsce na uwrażliwianie dzieci i młodzieży, że złe postępowanie ma konsekwencje (por. $\mathrm{AL}, \mathrm{nr}$ 268). Formacja moralna polega m.in. na obudzeniu w wychowanku umiejętności empatii: postawienia się w sytuacji innej osoby i zrozumienia, co może ona czuć, zwłaszcza wtedy, gdy jest krzywdzona. Pomocą w doprowadzeniu do takiego współodczuwania mogą być czasami mniej lub bardziej dotkliwe sankcje, dopuszczane zwłaszcza wtedy, gdy mamy do czynienia z agresywnymi zachowaniami antyspołecznymi (por. AL, nr 268).

Obok sankcji bardziej dotkliwych istotnym narzędziem wychowawczym jest także napomnienie. Ważne, aby tak ono, jak i wcześniej omawiana sankcja, stosowane były zawsze z miłością. Papież podkreśla, że dziecko napomniane z miłością czuje, że jest w kręgu zainteresowania, dostrzega, że jest 
kimś, spostrzega, iż jego rodzice uznają jego możliwości. Nie wymaga to, aby rodzice byli nieskazitelni, ale by byli w stanie pokornie uznać swoje ograniczenia i okazać swoje osobiste wysiłki, ku temu, by być lepszymi. Jednak świadectwem, którego dzieci potrzebują ze strony rodziców, jest to, by nie ulegali i nie dawali się ponieść złości. Dziecko, które popełnia zły czyn, musi być napomniane, ale nigdy jako wróg czy ktoś, na kim rozładowywana jest własna agresywność (por. AL, nr 269). Uwagi te wydają się niezwykle trafne i cenne, zwłaszcza że współcześnie rysują się dwie przeciwstawne sobie tendencje. Jedną jest liberalna pobłażliwość i niezwracanie uwagi wychowankom na ich niewłaściwe postępowanie, co wynika z relatywizmu moralnego oraz z błędnego przekonania, że własna niedoskonałość etyczna odbiera tytuł do korygowania zachowania dzieci i młodzieży. Drugą tendencją jest rygoryzm wychowawczy, do którego wkrada się złudne przekonanie, że strach przed karą jest jedynym narzędziem formacyjnym. Bywa, że temu przekonaniu towarzyszy stosowanie dotkliwych kar (w tym także cielesnych), będących emocjonalnym odwetem za nieposłuszeństwo, co nie ma nic wspólnego z ,napominaniem z miłością".

Dyscyplinowanie przez sankcję i napomnienie nigdy nie powinno ranić, ale być bodźcem do korygowania niewłaściwych postaw i zachowań. Dyscyplina wychowawcza ma być - jak pisze papież - „ograniczeniem konstruktywnym". Aby tak się stało, należałoby w procesie wychowawczym znaleźć równowage pomiędzy dwiema skrajnościami. Z jednej strony unikać łatwego ulegania pragnieniom dziecka, które chce być uznane za podmiot praw, ale nie obowiązków. Z drugiej wystrzegać się takiego podporządkowania wychowanka, które odbiera mu poczucie godności, unikalnej tożsamości i praw, a zadręcza go ciężarem obowiązków i realizowaniem woli innych.

Kolejnym istotnym instrumentem wychowawczym przywołanym przez Franciszka w adhortacji Amoris laetitia jest ćwiczenie w cierpliwości, które prowadzi do rozwoju zdolności oczekiwania i powściągliwości. Rodzina ze swej natury jest dogodnym środowiskiem kształtowania się tych postaw, gdyż w niej uczymy się stawać wobec innych, a to często oznacza konieczność ustąpienia, odczekania, odroczenia zaspokojenia jakiegoś pragnienia. Chodzi o umiejętność - jak to wyraził papież - „niestosowania prędkości cyfrowej we wszystkich dziedzinach życia” (AL, nr 275). Kultura powściągliwości i odroczenia jest szczególnie potrzebna w obecnej epoce, bardzo zdominowanej mentalnością korzystania z chwili, niepokojem i pośpiechem. Franciszek thumaczy zasady nieco dziś zapominane czy wręcz celowo spychane na dalszy plan. Przypomina, że 
odroczenie nie oznacza zaprzeczenia pragnienia, ale odłożenie jego zaspokojenia. Kiedy dzieci lub nastolatki nie są wychowane, aby przyjąć, że pewne rzeczy muszą poczekać, to stają się aroganckie, podporząadkowujące wszystko zaspokojeniu swoich doraźnych potrzeb i dorastają z wadą: „chcę wszystko i natychmiast”. Jest to wielkie oszustwo, które nie sprzyja wolności, ale ją zatruwa. Kiedy natomiast wychowujemy, aby nauczyć odkładania pewnych rzeczy i poczekania na stosowną chwilę, to uczymy wówczas, co znaczy być panem samego siebie, niezależnym od swoich impulsów (AL, $\mathrm{nr} 275)$.

Ta ogólna zasada pedagogiczna znajduje potwierdzenie i zastosowanie również w obszarze edukacji seksualnej. Wychowanie do miłości idzie zawsze $\mathrm{w}$ parze z moderowaniem pragnień i porządkowaniem ich w świetle personalistycznej hierarchii wartości, co wyraża się m.in. w postawie wstrzemięźliwości, czystości przedmałżeńskiej i odpowiedzialnym rodzicielstwie.

\section{Edukacja seksualna jako formacja do miłości - aktualne wyzwania}

Nakreślone powyżej pryncypia wychowania etycznego stanowią niezbędne podstawy szczególnej formy wychowania, jaką jest edukacja seksualna. Współcześnie istnieją różne modele tego typu edukacji odwołujące się do odmiennych systemów wartości. W literaturze najczęściej spotykamy systematykę wyróżniającą trzy typy edukacji seksualnej, nazywając je odpowiednio edukacją typu A, B lub $\mathrm{C}^{2}$. Edukacja seksualna, do której zachęca papież Franciszek, to edukacja w kontekście wychowania do miłości z uwzględnieniem personalistycznej wizji ludzkiej płciowości. Wychowanie seksualne nie jest odrębną dziedziną edukacji, oderwaną od innych aspektów wychowania człowieka, lecz wpisuje się w całościowy proces edukacyjny rozumiany jako integralny rozwój osoby. Jak zauważa Wanda Półtawska, „Przekazanie człowiekowi właściwej hierarchii wartości nazywamy wychowaniem, stąd można użyć takiego sformułowania, jak «wychowanie seksualne», jeżeli uczynimy zastrzeżenie, iż będzie to ogólne wychowanie człowieka z aplikacją do tej strony życia" (Półtawska 2005, s. 377).

W refleksji na temat edukacji seksualnej Franciszek wychodzi od przypomnienia zachęty Soboru Watykańskiego II do pozytywnego i mądrego

\footnotetext{
${ }^{2}$ Według klasyfikacji sporządzonej przez Amerykańską Akademię Pediatrii wyróżnia się trzy główne modele wychowania seksualnego: Model A (abstinence-only education) - akcentujący rolę abstynencji i wychowania do czystości przedmałżeńskiej; Model B (biological sex education) tzw. biologiczną edukację seksualną, promującą antykoncepcję i dość swobodny stosunek do norm moralnych w zakresie seksualności; Model C (comprehensive sex education) - złożoną edukację seksualną zawierającą oba powyższe podejścia (por. Kowalski 2008, s. 31).
} 
wychowania w tej dziedzinie, które będzie odpowiednio dostosowane do wieku dzieci i młodzieży, jak również uwzględni osiągnięcia nauk psychologicznych, pedagogicznych i dydaktycznych. Niestety, obok postulowanego przez Sobór integralnego podejścia do ludzkiej seksualności i płciowości zauważa się postępującą od lat tendencję do banalizacji tych sfer życia. W obliczu nasilającego się kryzysu w tej dziedzinie papież wzywa do rachunku sumienia, w jakim stopniu udało się zrealizować soborowe zalecenia, i zachęca do przeciwstawienia się smutnemu procesowi zubożenia wizji ludzkiej seksualności. Odzyskuje ona pełne znaczenie, gdy analizuje się ją w kontekście ludzkiej zdolności do stworzenia więzi, komunii osób i miłości wyrażającej się poprzez wzajemny dar z siebie. Edukacja seksualna ma prowadzić do zrozumienia, że ,impuls seksualny można wychowywać w procesie poznawania samego siebie i rozwijania zdolności do panowania nad sobą, które mogą pomóc w odkryciu cennych zdolności do radości i miłosnego spotkania" (AL, nr 280).

\section{a) Informacja $w$ parze $z$ formacją}

Edukacja seksualna jest jednocześnie informacją i formacją. Stanowi przekazanie niezbędnych wiadomości na temat funkcjonowania biologicznego, psychicznego i duchowego wymiaru ludzkiej płciowości, ma wprowadzić we właściwy sposób w rozumienie zróżnicowania płciowego, jego sensu i zadania. Informacja powinna być dostosowana do wieku i umiejętności percepcyjnych wychowanków oraz kształtować w nich zmysł krytyczny wobec tego wszystkiego, co dziś do nich dociera, a nie zawsze służy ich dobru. Zdaniem Franciszka, „młodzi ludzie powinni mieć możliwość uświadomienia sobie, że są bombardowani przesłaniami, które nie dążą do ich dobra oraz ich dojrzałości. Trzeba im pomóc w rozpoznaniu i poszukiwaniu wpływów pozytywnych, w czasie, w którym nabierają dystansu wobec tego wszystkiego, co zniekształca ich zdolność do kochania" (AL, nr 281).

Ze zdobytą informacją idzie w parze konieczność formacji rozumianej jako praktyczne zastosowanie wiedzy zdobytej teoretycznie. Mając na uwadze wiedzę o tym, kim jest człowiek, jak funkcjonuje we wszystkich wymiarach swojej złożonej istoty, w czym wyraża się sens jego życia, do czego jest zdolny i jak może kształtować swoje relacje z innymi, edukacja prowadzi do formułowania postulatów praktycznych, odpowiadających na pytania: Jak postępować? Co jest godne człowieka i jego osobowej natury? Co jest moralnie godziwe, a czego nie można zaakceptować? Wychowanie seksualne, uświadamiając dzieci i młodzież w zakresie wartości i znaczenia 
ludzkiej płciowości, nie może pomijać faktu, że jest ona również obszarem wielorakich zranień i krzywd i dlatego domaga się respektowania zasad moralnych regulujących dojrzałe przeżywanie tej sfery życia ludzkiego.

Wrodzoną formą obrony przed zranieniami w sferze seksualnej jest zdrowa skromność, którą Franciszek definiuje jako „naturalną obronę osoby, chroniącej swe wnętrze i unikającej zamienienia się jedynie w przedmiot" (AL, nr 282). Gdy jej zabraknie, pojawia się ryzyko, że płciowość i ludzkie uczucia zostaną sprowadzone do poziomu odruchów, a człowiek popadnie $\mathrm{w}$ obsesję koncentrującą go na doznaniach płynących z reakcji dziejącej się w narządach płciowych. Taka obsesyjna koncentracja na doznawaniu przyjemności na pewno nie służy rozwojowi osoby, zamyka ją raczej w kręgu własnych odczuć i utrudnia wyjście ku innym. W ten sposób zniekształca się ludzka zdolność do miłości, a sam człowiek popada w różne stany uzależnień bądź sięga po zakamuflowane lub jawne formy przemocy seksualnej, które czynią z seksualności mroczny świat poniżania innych i traktowania ich jak używane przedmioty.

Niestety, z podobnym urzeczowieniem osoby mamy do czynienia w przypadku coraz powszechniejszego stosowania różnego rodzaju środków antykoncepcyjnych. Odczłowieczenie relacji intymnej ma miejsce zarówno przez częste wymuszanie współżycia przez mężczyzn na kobietach, które muszą się zabezpieczać, aby zaspokoić nieopanowaną żądzę mężczyzn. Po drugie, eufemistyczne wyrażenie „bezpieczny seks” oznacza jednocześnie, że pragnienie przyjemności stawia się wyżej aniżeli ewentualne dziecko, które mogłoby przyjść na świat w wyniku współżycia. Franciszek nie pozostawia tu cienia wątpliwości. Wyrażenia typu ,zabezpieczenie przed ciążą, czy „,bezpieczny seks” sugerują „,negatywny stosunek do naturalnego prokreatywnego celu seksualności, tak jakby ewentualne dziecko było wrogiem, przed którym trzeba się bronić. W ten sposób krzewiona jest narcystyczna agresja a nie życzliwość" (AL, nr 283).

\section{b) Wobec banalizacji ludzkiej seksualności}

Innym problemem, z jakim zmierzyć się musi współcześnie wychowanie, jest banalizacja ludzkiej seksualności przez sprowadzanie jej do sfery zabawowo-rekreacyjnej. Jak zauważa Józef Wróbel, międzyosobowe relacje angażujące ludzką płciowość coraz częściej postrzegają ją w fałszywym świetle. „Przypisuje się jej charakter ludyczny, wolny od pogłębionej refleksji nad jej sensem osobowym i właściwymi jej funkcjami. Proces ten jest bezsprzecznie owocem uświadomienia zredukowanego do anatomii i fizjologii, technik współżycia, a także propagowania środków antykon- 
cepcyjnych i możliwości aborcji” (Wróbel 2010, s. 136). Należy wskazać również drugą przyczynę banalizacji ludzkiej płciowości. Jest nią szukanie łatwej formy relaksu i odprężenia. Seksualność ze swym zmysłowo-afektywnym wymiarem stała się łatwo dostępnym źródłem odreagowania i przyjemności. „Człowiek żyjący na co dzień w stresogennych warunkach szuka coraz łatwiejszych form relaksu z wewnętrznych napięć. [...] Relaksujący charakter doświadczeń seksualnych, zwłaszcza w niezobowiązującym zbliżeniu, uwolniony od strachu przed ciążą i chorobami przenoszonymi drogą płciową, dobrze służy tym potrzebom" (Wróbel 2010, s. 136).

Z uwagi na świadomość tych niepokojących zjawisk papieżowi leży na sercu szczególnie los dzieci i młodzieży, ponieważ chce je uchronić przed wyżej nakreśloną mentalnością. Stąd stanowczo potępia jako nieodpowiedzialne takie zajęcia w ramach edukacji seksualnej, które zachęcają nastolatków, aby bawili się swoim ciałem i swoimi pragnieniami (por. AL, nr 283). Zwraca także uwagę na fakt, że mentalność ludyczna przyzwala nieletnim na takie działania w sferze seksualnej, jak gdyby byli już dojrzali i mogli angażować się w to, co przysługuje małżonkom. Skutkuje to, niestety, poważnymi konsekwencjami w postaci traktowania innych osób jak rzeczy, które się używa dla dostarczenia przyjemności, co miałoby zrekompensować głód autentycznej bliskości i miłości. Tymczasem przyjemność zmysłowa nigdy nie zastąpi człowiekowi miłości, więzi, poczucia bezpieczeństwa i akceptacji, jakie płyną ze stabilnego związku. Uwzględniająca ten fakt edukacja seksualna powinna być wychowaniem do miłości. Zdaniem Franciszka, wychowanków należy

nauczyć drogi prowadzącej przez różne przejawy miłości, wzajemnej troski, szacunku naznaczonego czułą troską, bogatego w znaczenia komunikowania się. Wszystko to przygotowuje bowiem do pełnego i hojnego daru z siebie, który wyrazi się po ślubie $\mathrm{w}$ darze ciał. Zjednoczenie seksualne w małżeństwie przejawi się wówczas jako znak zaangażowania całościowego, ubogaconego całą wcześniejszą drogą (AL, nr 283).

W tym kontekście papież przypomina również fundamentalne rozróżnienie pomiędzy pociągiem seksualnym a osobową miłością. Pierwszy, sam w sobie dobry, tworzy jednak złudzenie trwałego związku, będąc z natury nietrwałym i zmiennym ${ }^{3}$. Jako taki domaga się dopełnienia miłością osobową, która odpowiednio go odczyta, zinterpretuje i zintegruje/włączy w całość doświadczenia międzyosobowego spotkania prowadzącego do wzajemnego daru $\mathrm{z}$ siebie. W przeciwnym razie może się zdarzyć, że chcąc dać wszystko w jednej chwili emocjonalnego uniesienia, nie da się niczego. Trzeba przed tym ry-

\footnotetext{
${ }^{3}$ Franciszek cytuje w tym miejscu trafną obserwację Ericha Fromma: „Pociąg seksualny tworzy na krótko złudzenie związku, a jednak bez miłości «związek» ten pozostawia obcych równie daleko od siebie, jak byli dotąd" - Fromm 1971, s. 68.
} 
zykiem ostrzegać młodzież, będąc wyrozumiałym dla niezawinionej słabości wynikającej z wieku lub zagubienia. Nie można jednocześnie zgadzać się na „pobudzanie młodzieży do przedłużenia niedojrzałości w ich sposobie miłowania” (AL, nr 284). Wskazywanie młodzieży na tę różnicę i pomaganie jej w kształtowaniu właściwych postaw jest wyrazem szacunku do niej i traktowania młodych ludzi na serio. „Kto jednak mówi dziś o tych rzeczach?” - pyta retorycznie papież i konkluduje z goryczą: „Nazbyt lekko traktuje się edukację seksualną" (AL, nr 284).

\section{c) Zróżnicowanie płciowe: kultura w harmonii z naturą}

Ostatnim wyzwaniem, wobec którego staje współcześnie edukacja seksualna, jest kwestia różnicy płciowej kobiety i mężczyzny. Zagadnieniu temu papież poświęca dwa obszerne punkty adhortacji, dając tym samym poznać, jak bardzo zagadnienie to leży mu na sercu. Zwłaszcza w obliczu nasilającej się promocji ideologii gender tematyka ta nabiera szczególnej wagi i nie może być bagatelizowana ani przez Magisterium Kościoła, ani przez teologów czy wychowawców. Klimat kulturowy, jaki wytworzył się w ostatnich dziesięcioleciach wokół problematyki zróżnicowania płciowego, kobiecości i męskości, nie ułatwia dzieciom i młodzieży odczytania ich własnej tożsamości płciowej i odnalezienia się w gąszczu niedookreślonych ról i relacji. Dlatego, rozumiejąc te współczesne trudności, edukacja seksualna powinna

pomóc w akceptacji swojego ciała, takim jakim zostało stworzone, ponieważ „logika dominacji nad własnym ciałem przekształca się niekiedy w subtelną logikę panowania nad stworzeniem. [...] Także docenienie własnego ciała w jego kobiecości lub męskości jest konieczne, aby móc rozpoznać siebie w spotkaniu $\mathrm{z}$ innym, różnym od siebie. $\mathrm{W}$ ten sposób można z radością przyjąć specyficzny dar drugiego czy drugiej jako dzieła Boga Stwórcy i wzajemnie się ubogacić" (AL, nr 285).

Zdaniem Franciszka, w refleksji na temat ludzkiej płciowości nie możemy ignorować podstawowego faktu potwierdzonego przez biblijne objawienie, że zróżnicowanie płciowe, wyrażone w kobiecości i męskości, jest chciane przez Pana Boga i jako takie jest uprzednie wobec wszelkich ludzkich decyzji i doświadczeń. Częścią składową stanowiącą o tym zróżnicowaniu są czynniki biologiczne, których nie wolno nam ignorować (por. AL, $\mathrm{nr} 286)^{4}$.

\footnotetext{
${ }^{4} \mathrm{~W}$ tym miejscu nie można nie wspomnieć o błędzie w polskim tłumaczeniu tekstu adhortacji Amoris laetitia, opublikowanego oficjalnie na internetowej stronie Stolicy Apostolskiej (por. https://w2.vatican. $\mathrm{va} /$ content/francesco/pl/apost_exhortations/documents/papa-francesco_esortazione-ap_20160319_amoris-
} 
Papież zdecydowanie odrzucił konstruktywistyczną koncepcję płci, jaka przyjęła się w poglądach radykalnego genderyzmu. Nie wyklucza jednak możliwości niezideologizowanej refleksji nad kulturowymi uwarunkowaniami rozumienia płci, jak również dopuszcza uwzględnienie owoców tego namysłu w edukacji seksualnej. W całościowo potraktowanej refleksji nad ludzką płciowością wyjść należy od biblijnego opisu stworzenia, w świetle którego poznajemy pełen mądrości i miłości zamysł Boży dotyczący kobiety i mężczyzny. Oboje są chciani i powołani do istnienia w komplementarnej różnicy płciowej.

Podejmując zatem analizę kulturowych czynników wpływających na rozumienie płci, nie można ignorować tego, że człowiek jest powołany do akceptacji psycho-fizycznej złożoności swojej natury. Jest także powołany do akceptacji własnego ciała z jego wewnętrznym logosem i sensem oraz celowością poszczególnych narządów. Dopiero po uświadomieniu sobie tego pryncypium mówiącego o uprzedniości ludzkiej natury wobec kultury można podjąć dalsze badania nad wpływem funkcjonujących już w kulturze sposobów interpretacji kobiecości i męskości. Również w edukacji seksualnej kolejność tę trzeba uwzględnić, aby właściwie zrozumieć, co znaczą słowa Franciszka, który stwierdza, że „to co męskie i kobiece, nie jest czymś sztywnym” (AL, nr 286). Trzeba przyznać, że słowa te nie brzmią zbyt precyzyjnie i mogą sugerować istnienie jakiejś niedookreśloności lub płynności tożsamości płciowej. Na szczęście papież natychmiast dodaje, w jakim sensie rozumie ową

laetitia.html [dostęp: 23.05.2017]). Błędne thumaczenie zostało poprawione po interwencji autora niniejszego artykułu w Sekcji Polskiej Sekretariatu Stanu Stolicy Apostolskiej, niemniej jednak w wersji papierowej zostało rozpowszechnione wcześniej w tysiącach egzemplarzy, np. przez Wydawnictwo M czy inne. Błąd pojawił się w numerze 286. i ma on moim zdaniem bardzo poważne konsekwencje w rozumieniu przesłania, z jakim papież zwraca się w tym fragmencie. Otóż błędnie przetłumaczone zdanie sugeruje, jakoby w dziele stwórczym Pana Boga nie można było odróżnić tego, co kobiece, i tego, co męskie. Cytuję: „To prawda, że nie możemy oddzielić tego, co jest męskie i żeńskie w dziele stworzonym przez Boga... (jakby w dziele stworzenia powołany został do istnienia jakiś hermafrodytyczny byt). Tymczasem w tekście włoskim umieszczonym na oficjalnej stroni Stolicy Apostolskiej czytamy: „È vero che non possiamo separare ciò che è maschile e femminile dall'opera creata da Dio...”, co należy tłumaczyć następująco: „To prawda, że nie możemy oddzielać tego, co jest męskie i żeńskie od dzieła stworzonego przez Boga". Błąd tłumaczenia w j. polskim jest poważny, gdyż sprawia, że rozumiemy, iż w dziele stwórczym Pana Boga nie ma żadnych przesłanek do przyjęcia obiektywnej i chcianej przez Boga różnicy płci (nie da się w dziele stworzonym oddzielić tego, co kobiece, i tego, co męskie). Tymczasem tekst opublikowany na stronach Stolicy Apostolskiej w innych językach mówi, że tego, co kobiece i męskie nie można oddzielać od woli Boga, która wyraziła się w dziele stworzenia mężczyzny i kobiety. Kobiecość i męskość w swej różnorodności jest od początku zamierzona przez Boga-Stwórcę. Dla pewności podaję jeszcze brzmienie tego samego fragmentu w j. niemieckim oraz hiszpańskim: „Es ist wahr, dass man das, was männlich und weiblich ist, nicht von dem Schöpfungswerk Gottes trennen kann”; „Es verdad que no podemos separar lo que es masculino y femenino de la obra creada por Dios" (por. Amoris laetitia, http://w2.vatican.va). W dniu 31 maja 2017 błędnie thumaczone zdanie brzmiało już poprawnie: „To prawda, że nie możemy oddzielić tego, co jest męskie i żeńskie od dzieła stworzonego przez Boga, które jest uprzednie wobec wszystkich naszych decyzji i doświadczeń, i gdzie istnieją elementy biologiczne, których nie można ignorować" - https://w2.vatican.va/content/francesco/pl/apost_exhortations /documents/papa-francesco_esortazione-ap_20160319_amoris-laetitia.html [dostęp: 31.05.2017]. 
„sztywność”. Nie odnosi jej do istoty kobiecości i męskości, która w świetle wcześniejszych rozważań jest uprzednia, zastana i nie można w nią ingerować, lecz do ról i funkcji, jakie kobiety i mężczyźni mogą przyjmować w społeczeństwie. Chodzi zatem o pewną możliwość dostosowania się, wymiany obowiązków, podjęcia zadań, które czasem zbyt sztywno uznaje się za jedynie kobiece lub jedynie męskie. Zdaniem Franciszka, taka

sztywność staje się przesadną manifestacją tego, co męskie lub kobiece i nie wychowuje dzieci i młodzieży do wzajemności realizującej się w rzeczywistych warunkach małżeństwa. Owa sztywność może z kolei uniemożliwić rozwój zdolności każdego, aż do tego stopnia, że uważa się za coś mało męskie poświęcenie się sztuce lub tańcowi, a mało kobiece pełnienie funkcji kierowniczych. To, Bogu dzięki, zmieniło się, ale w niektórych miejscach pewne niewłaściwe koncepcje nadal wpływają na ograniczanie uzasadnionej wolności i okaleczenie prawdziwego rozwoju konkretnej tożsamości dzieci oraz ich potencjału (AL, nr 286).

W świetle powyższych słów możemy stwierdzić, że papież Franciszek zachęca wychowawców do szczerej i niezideologizowanej analizy kulturowych uwarunkowań rzutujących na rozumienie kobiecości i męskości, aby lepiej zrozumieć ich wpływ na kształtowanie się poczucia tożsamości i ról społecznych. Wychowawcy nie powinni jednak zapominać o tym, że kultura nie może niszczyć natury. Dlatego refleksja nad ludzką płciowością uwzględniać powinna w równej mierze zarówno uwarunkowania kulturowe, jak i czynniki biologiczne bazowo determinujące kobiecość i męskość.

Ludzka seksualność ma niekwestionowalną wartość i jest czynnikiem kształtującym poziom szczęścia i satysfakcji w życiu człowieka. Poziom ten zależy jednak w znacznej mierze od stopnia panowania nad impulsem seksualnym, który można wychować poprzez poznawanie siebie i kształtowanie odpowiednich postaw prowadzących do miłosnego spotkania osób. Edukacja seksualna jako wychowanie do miłości powinna opierać się na fundamentalnych zasadach wychowania etycznego, do których należą: afirmacja osoby ludzkiej powiązana z prewencją wobec zagrożeń jej godności, kształtowanie sumienia i sprawności moralnych pomagających w krzewieniu odpowiedzialnej wolności, kształtowanie postawy powściągliwości i czystości. Powyższe instrumentarium pedagogiczne pozwoli przygotować dzieci i młodzież do stawiania czoła różnorakim deformacjom i dewiacjom w sferze ludzkiej seksualności, pomoże występować przeciw banalizacji ludzkiej seksualności oraz przeciwstawiać się tendencjom odrywającym kulturę od natury. Ludzka płciowość to nie tylko wypadkowa kulturowych interpretacji, ale również uprzednie wobec ludzkich stanów emo- 
cjonalnych i pragnień obiektywne dane biologii, cielesności, realizm narządów i układów ludzkiego zdeterminowanego płciowo organizmu. Czynniki biologiczne mają niekwestionowane znaczenie w odczytaniu tak osobistej tożsamości, jak i zadań społecznych kobiety i mężczyzny, do których należą m.in. macierzyństwo i ojcostwo, będące fundamentem przyszłości społeczeństw. Wychowanie, które chce pozostać wierne swej pierwotnej misji, nie może nigdy stracić z pola widzenia perspektywy przyszłości. Jest bowiem troską o wychowanka w perspektywie jego jutra, a oblicze tego jutra w dużej mierze zależy od rozumienia i przeżywania przez człowieka swojej własnej seksualności i płciowości.

\author{
SEX EDUCATION AS EDUCATION FOR LOVE. \\ CONSTANT PRINCIPLE AND NEW CHALLENGES \\ IN THE LIGHT OF AMORIS LAETITIA 259-290
}

\title{
SUMMARY
}

The issue of sexual education raises emotional discussions and polemics in the public space.

In the Apostolic Exhortation Amoris laetitia Pope Francis encourages an in-depth reflection on this issue in the light of the educational principles inspired by the wisdom of the Gospel. The author of this paper recalls the principle of the sexual education: affirmation of the dignity of the person and shaping responsible freedom through the formation of moral conscience and virtues, as well as the principle of restraint and chastity. They are essential and necessary for taking current challenges of education, including proper moral formation, banalisation of sexuality or gender ideology.

Słowa kluczowe: edukacja seksualna; gender; płeć; seksualność; wychowanie do miłości

Keywords: sex education; gender; sexuality; education for love

\section{BIBLIOGRAFIA}

\section{Źródło}

Franciszek (2016), Posynodalna adhortacja apostolska Amoris laetitia, Kraków.

\section{Literatura pomocnicza}

Fromm E. (1971), O sztuce miłości, Warszawa.

Görres A. (1997), Uwagi psychologiczne na temat grzechu pierworodnego i jego skutków, w: C. Schönborn, A. Görres, R. Spaemann, Grzech pierworodny w nauczaniu Kościoła, Poznań, s. 9-28. 
Kowalski S. (2008), Polski model «wychowania do życia w rodzinie» przynosi dobre rezultaty. „Służba Życiu” 1(2008), s. 31.

Półtawska W. (2005), Wychowanie seksualne częścia wychowania człowieka, w: Wychowanie personalistyczne, red. F. Adamski, Kraków, s. 377-390.

Wróbel J. (2010), Wychowanie seksualne z perspektywy nauczania Magisterium Kościoła katolickiego, w: Wychowanie seksualne w rodzinie $i$ w szkole, red. K. Glombik, Opole, s. 133-152.

MACIEJ OLCZYK - ks. dr hab. prof. UAM, jest pracownikiem naukowym w Zakładzie Teologii Moralnej, Duchowości i Katolickiej Nauki Społecznej na Wydziale Teologicznym Uniwersytetu im. A. Mickiewicza w Poznaniu. Prowadzi badania w zakresie etyki teologicznej. Autor publikacji z zakresu teologii moralnej fundamentalnej, antropologii teologicznej, teologii małżeństwa i rodziny, bioetyki oraz etyki seksualnej. W swoich pracach nawiązuje do aktualnych problemów społecznych, dylematów etycznych i zachodzących przemian obyczajowych. 